GEOGRAFICKÝ ČASOPIS / GEOGRAPHICAL JOURNAL 72 (2020) 1, 71-80

DOI: https://doi.org/10.31577/geogrcas.2020.72.1.04

\title{
FACETED CLASSIFICATION OF THE SPRING FLOOD HYDROGRAPHS OF THE SOUTHERN BUH RIVER
}

\author{
Borys Khrystiuk*, Liudmyla Gorbachova*, Viktoria Prykhodkina* \\ *Ukrainian Hydrometeorological Institute, Department of hydrological researches, 37, Prospekt Nauki, \\ Kyiv, Ukraine, 03028, khryst@uhmi.org.ua
}

\begin{abstract}
Faceted classification of the spring flood hydrographs of the Southern Buh river
A hydrograph shape reflects the effect of hydrological, hydrobiological, hydromorphological, hydrochemical and other processes acting in river basins. Classification of river hydrographs could help to evaluate the long-term changes in river basins or compare hydrological response of different basins. We present the methodology of the spring flood hydrograph classification and show its application in the Southern Buh River basin, Ukraine. The methodology uses faceted classification employing a multidimensional statistical approach and a controlled number of classes. We analyze daily discharge data for 102 spring flood hydrographs of the Southern Buh River from the period $1914-2015$. Classification of hydrographs taking into account the date of the beginning, peak and end of the spring flood flows and the peak discharge provides 81 classes, while only ten of them contained three and more hydrographs. The most frequent hydrograph shapes are EEEL ${ }_{\mathrm{d}}$ (early beginning, peak and end of spring flood, low peak discharge) and $\mathrm{LLLH}_{\mathrm{d}}$ (late beginning, peak and end of spring flood, high peak discharge) that contain 8 and 10 hydrographs, respectively. While the majority of hydrographs falling in the class $\mathrm{LLLH}_{\mathrm{d}}$ occurred until the end of the 1960's, the hydrographs from the $\mathrm{LLLH}_{\mathrm{d}}$ were mostly observed in the last three decades.
\end{abstract}

Key words: hydrograph shape, faceted classification, spring floods, peak discharge, Southern Buh river

\section{INTRODUCTION}

A river hydrograph provides a graphical representation of temporal discharge fluctuations. It is the main source of information for the investigation of the different hydrological regimes of river - spring flood, rain flood and low water (Hannah et al. 2000 and Ternynck et al. 2015). In Ukraine, on plain rivers, the spring flood is a typical feature of the hydrological regime. The formation of spring floods is determined by the variability of climatic factors, which result in quite different hydrograph shapes. Such characteristics of spring flood as the peak discharge, volume and depth of runoff cannot describe the hydrograph shapes of the river. However, knowledge about the hydrograph shape are used in many theoretical and practical problems in hydrology (Yue et al. 2002, Candela et al. 2014 and Pol 2014). The attention of scientists has more often focussed on the research of various hydrograph shapes in the last two decades (Rushmer et al. 2002, Perkins and Jones 2008, Gjunsburgs et al. 2010, Ternynck et al. 2015, Phillips et. al. 2016 and Oppel and Schumann 2018). The basis of such research is the classification of river hydrographs. Grouping of hydrographs with a similar shape in the classes improves understanding of various hydrological regimes of the river, especially during periods of flood and drought (Ternynck et al. 2015). Such research is very rare in Ukraine (Khrystyuk et al. 2017).

Usually, the classification of any objects is carried out in the two systems: hierarchical and faceted. The hierarchical system is the most widespread, not only in hydrology, but also in other spheres. The hierarchical system establishes the rela- 
tion of subordination between different groups, which are formed on certain features. In this case, the set of received groups forms a hierarchical tree structure. The faceted system of classification supposes that the data is divided into groups based on independent classification criteria - facets (Makarova and Volkova 2015). The most common methods of classification of river hydrographs are multidimensional and functional analyzes (Ternynck et al. 2015, Brunner et al. 2018 and Oppel et al. 2018). When using a multidimensional approach, river hydrographs are described by different parameters, the number of which is determined by researchers. More parameters allow better description of the hydrographs, but at the cost of more complicated classification. In the functional approach, the hydrographs are described by a curve expressed by a formula (function). The classification can be controlled or uncontrolled (Hartigan 1975). In the first case, the number of classes is known in advance or set by the applied criteria. The number of classes in the uncontrolled classification is not known. Faceted classification was introduced by the Indian scientist Sh. R. Ranganathan in 1933 (Ranganathan 2006). Such a classification system uses a set of semantically linking categories that are combined as needed to create a concept. It makes the classification quite flexible. Owing to the flexibility of the structure, the method has been widely used in many areas.

The objective of this paper is to develop a faceted classification of spring flood hydrographs and apply it to the Southern Buh River basin.

\section{STUDY AREA}

Southern Buh is the largest plain river of Ukraine. Its basin is located in southwestern and south-central Ukraine (Fig. 1). The length of the river is $806 \mathrm{~km}$, and the area of its drainage basin is $63700 \mathrm{~km}^{2}$. The headwater area is located in in the Volyn-Podillia Upland at an altitude of $321 \mathrm{~m}$ above sea level. The river flows into the Dnieper-Buh estuary of the Black Sea. The climate of the upper and the middle parts of the basin is moderate continental. The climate of the southern regions is influenced by the Black Sea and it becomes dry in the lower reach of the river (Bauzha and Gorbachova 2017).

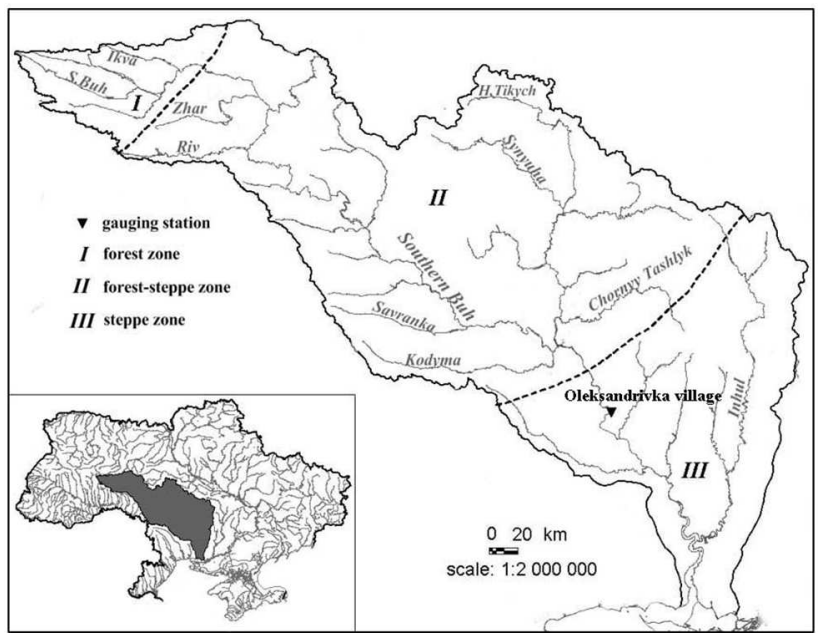

Fig. 1. Scheme of natural zones and location of the Oleksandrivka village gauging station in the Southern Buh river basin 
The flow regime is characterized by spring and rain floods that are followed by low-water periods during the year. The spring flood period represents 35 to $60 \%$ of annual streamflow (Shakirzanova and Kazakova 2015). The highest annual discharges are observed during the spring flood period. The timing and magnitude of the spring floods are determined by the amount of snow, snowmelt, and the amount of rainfall during the spring season (Gorbachova and Khrystiuk 2018). The combination of these factors determines the formation of different hydrograph shapes.

\section{MATERIALS AND METHODS}

Faceted classification is a controlled classification and divides the hydrographs into independent groups (classes) according to pre-set various classification features - facets (Makarova et al. 2015). Each facet contains a certain value of the characteristics of the flood hydrographs. The characteristics should allow a detailed description of a variety hydrograph shapes and be easily obtained from available data. Peak discharge and the date of its occurrence, along with the start and end dates of the spring floods, are used as characteristics in this study. As a result, four facets, each of which contains three values, are created (Tab. 1). All possible combinations of classification features result in 81 hydrographs classes. The ranges of values for each facet are determined by statistical processing of the data -mean values, standard deviations, coefficients of variation (Chow et al. 1988).

Tab. 1. Scheme of the faceted classification of spring flood hydrographs

\begin{tabular}{cccc}
\hline $\begin{array}{c}\text { the start of the spring } \\
\text { flood }\left(\mathrm{X}^{1}\right)\end{array}$ & $\begin{array}{c}\text { Date } \\
\text { the occurrence of the } \\
\text { peak discharge }\left(\mathrm{X}^{2}\right)\end{array}$ & $\begin{array}{c}\text { the end of the spring } \\
\text { flood }\left(\mathrm{X}^{3}\right)\end{array}$ & $\begin{array}{c}\text { The value of the peak } \\
\text { discharge }\left(\mathrm{X}^{4}\right)\end{array}$ \\
\hline early (E) & early $(\mathrm{E})$ & early $(\mathrm{E})$ & highest $\left(\mathrm{H}_{\mathrm{d}}\right)$ \\
mean (A) & mean $(\mathrm{A})$ & mean $(\mathrm{A})$ & mean $\left(\mathrm{A}_{\mathrm{d}}\right)$ \\
late (L) & late $(\mathrm{L})$ & late $(\mathrm{L})$ & lowest $\left(\mathrm{L}_{\mathrm{d}}\right)$ \\
\hline
\end{tabular}

The above-mentioned methodology is used to classify spring flood hydrographs of the Southern Buh river at the Oleksandrivka village water gauging station for the period 1914 - 2015 (102 hydrographs).

\section{RESULTS}

Analysis of daily discharges shows that hydrographs having a clearly distinct spring flood shape can start in January and end in the first days of June (Fig. 2). The highest discharges during spring floods can finish at the end of April (Fig. 2 a). The flood peak is observed in the middle and end of March. Analysis hydrographs of the Southern Buh river showed that the deviations of some hydrographs from the mean hydrograph (for the period $1914-2015$ ) vary quite a lot (Fig. 2 b). This is caused by different climatic conditions of spring flood formation in each year. The highest spring floods have the sawtooth shapes.

Statistical distribution of the dates of the start and end of spring floods and the dates of the peak discharges are close to normal distribution. The values of the peak discharges have an asymmetric distribution (Fig. 3). Consequently, the range $\pm 0,355 \sigma$ was adopted for the mean dates of the spring flood start, and end the mean 
date of the peak discharge. The probability of the dates in this range is $30 \%$. Dates outside this range are classified as early $(<-0.355 \sigma)$ and late $(>0.355 \sigma)-$ Tab. 2 .
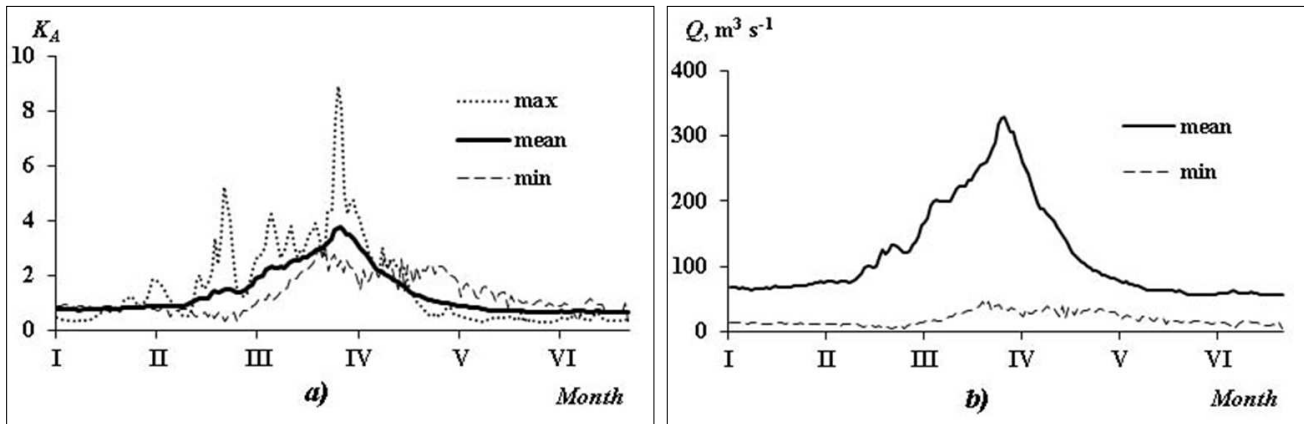

Fig. 2. Daily discharges of the spring floods of the Southern Buh river at Oleksandrivka village water gauging station in period $1914-2015$

Source: own research.

Note: $K_{A}$ is the modular coefficient that is determined as ratio $K_{A}=A_{i} / \bar{A}$, where $A_{i}$ is the value $i$-element of the series and $\bar{A}$ is the average of the series.

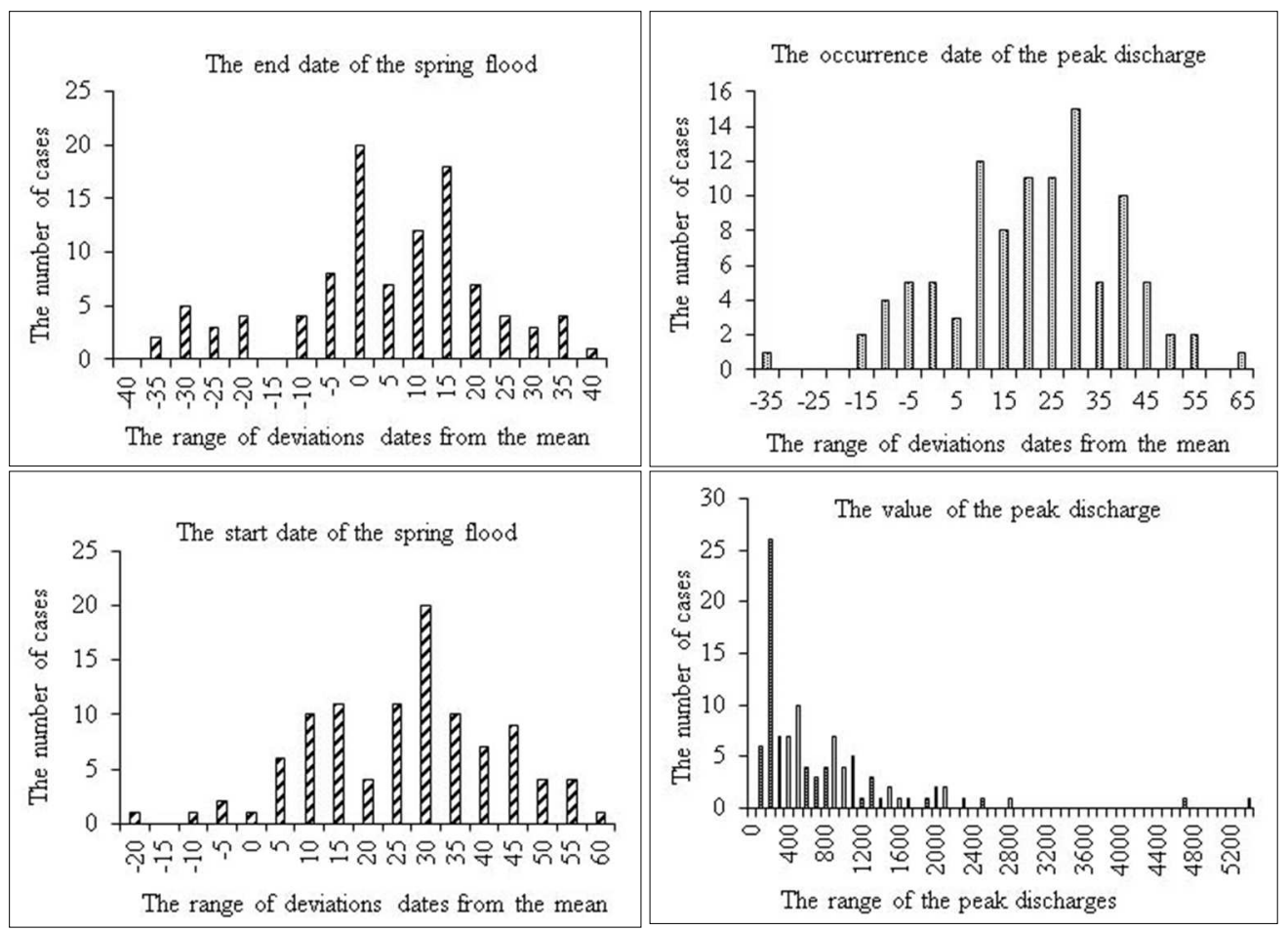

Fig. 3. Histograms of the dates of start and end of spring floods and the occurrence and the value of peak discharge

Source: own research. 
Tab. 2. The start and end dates of spring floods, the occurrence dates of peak discharge of the Southern Buh river at Oleksandrivka village water gauge for the period $1914-2015$

\begin{tabular}{|c|c|c|c|c|c|}
\hline \multicolumn{3}{|c|}{ Date } & \multirow{2}{*}{$\sigma$} & \multicolumn{2}{|c|}{ Date with probability } \\
\hline mean & early & late & & $-0,355 \sigma$ & $+0,355 \sigma$ \\
\hline \multicolumn{6}{|c|}{ the start of the spring flood } \\
\hline February 25 & January 11 & March 27 & 15.6 & February 19 & 3 March \\
\hline \multicolumn{6}{|c|}{ the occurrence of the peak discharge } \\
\hline March 19 & January 25 & May 2 & 17.7 & March 13 & March 25 \\
\hline \multicolumn{6}{|c|}{ the end of the spring flood } \\
\hline May 3 & March 23 & June 6 & 16.7 & April 27 & May 9 \\
\hline
\end{tabular}

The range 33.3-66.7\% was adopted for the mean of the peak discharge. The discharges outside of this range are classified as highest $(<33.3 \%)$ and lowest $(>66.7 \%)-$ Tab. 3 .

Tab. 3. The value of the peak discharge of the spring flood of the Southern Buh river at Oleksandrivka water gauging station for the period $1914-2015$

\begin{tabular}{ccccc}
\hline \multicolumn{3}{c}{ The peak discharge, $\mathrm{m}^{3} \mathrm{~s}^{-1}$} & \multicolumn{2}{c}{ The peak discharge with probability, $\mathrm{m}^{3} \mathrm{~s}^{-1}$} \\
\hline mean & highest & lowest & $33.3 \%$ & $66.7 \%$ \\
733 & 5320 & 76 & 736 & 278 \\
\hline
\end{tabular}

For the faceted classification, 102 hydrographs were used (Fig. 4). They are characterized by a significant variety and complexity of shapes. Spring floods in individual years have different dates of the start, end and occurrence of peak discharge, as well as peak discharge value. In some years, the rains fell during the spring flood. Sometimes periods of thaw and cold weather were observed.

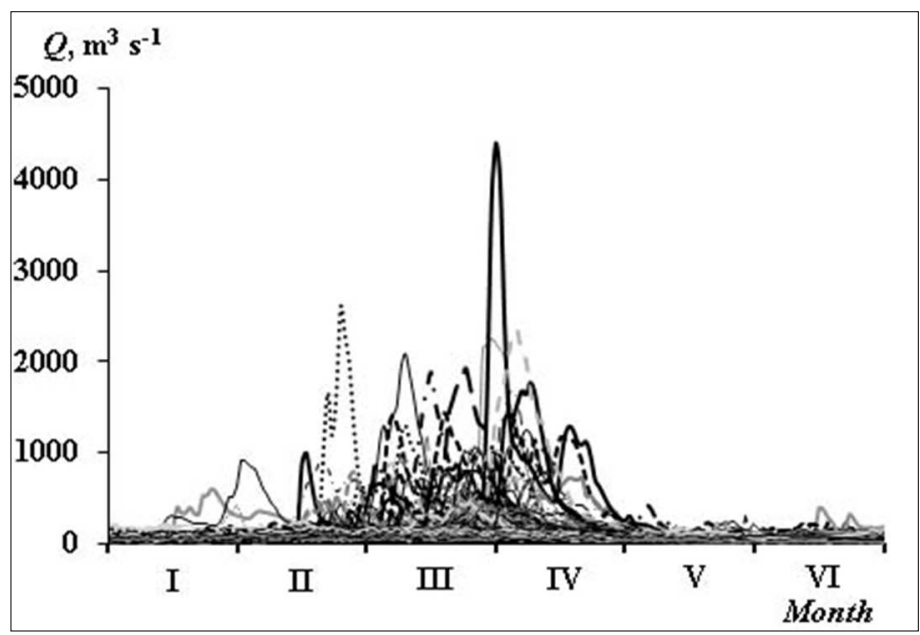

Fig. 4. Hydrographs of the spring floods of the Southern Buh river at Oleksandrivka water gauging station for the period $1914-2015$

Source: own research. 
Distribution of spring floods according to faceted classification is given in Tab. 4

Tab. 4. Results of the faceted classification hydrographs of the Southern Buh river at Oleksandrivka water gauging station for the period $1914-2015$

\begin{tabular}{|c|c|c|c|c|c|}
\hline $\begin{array}{l}\text { Number } \\
\text { of class }\end{array}$ & $\begin{array}{l}\text { Facet of value } \\
\left(X^{1} X^{2} X^{3} X^{4}\right) \\
\end{array}$ & $\begin{array}{l}\text { Years in which hydrographs } \\
\text { with a similar shape were } \\
\text { observed }\end{array}$ & $\begin{array}{l}\text { Number } \\
\text { of class }\end{array}$ & $\begin{array}{l}\text { Facet of value } \\
\left(X^{1} X^{2} X^{3} X^{4}\right)\end{array}$ & $\begin{array}{l}\text { Years in which hydrographs } \\
\text { with a similar shape were } \\
\text { observed }\end{array}$ \\
\hline 1 & $\mathrm{EEE} \mathrm{L}_{\mathrm{d}}$ & $\begin{array}{l}1957,1974,1990,1995, \\
1997,2002,2004,2014\end{array}$ & 42 & $\mathrm{M} \mathrm{M} \mathrm{M} \mathrm{H}_{\mathrm{d}}$ & 1926,1967 \\
\hline 2 & E E E $M_{d}$ & 1938,1950 & 43 & M M L L & 1954 \\
\hline 3 & $\mathrm{E} E \mathrm{E} \mathrm{H}_{\mathrm{d}}$ & 1977,1960 & 44 & M M L M & 1946 \\
\hline 4 & E E M L $L_{d}$ & $1914,1930,2000$ & 45 & M M L H & $1920,1947,1979$ \\
\hline 5 & E E M M $M_{d}$ & 1948 & 46 & M L E L $\mathrm{L}_{\mathrm{d}}$ & - \\
\hline 6 & $\mathrm{E} \mathrm{E} \mathrm{M} \mathrm{H}$ & - & 47 & M L E $M_{d}$ & - \\
\hline 7 & $\mathrm{E} E \mathrm{~L} \mathrm{~L}_{\mathrm{d}}$ & 1918 & 48 & M L E H & 1953 \\
\hline 8 & E E L M & 1958,1966 & 49 & $M L ~ M L_{d}$ & 1998,2008 \\
\hline 9 & $\mathrm{E} E \mathrm{~L} \mathrm{H}_{\mathrm{d}}$ & 1941 & 50 & M L M M & 1976,1988 \\
\hline 10 & E M E L $\mathrm{L}_{\mathrm{d}}$ & 1972 & 51 & M L M H & 1962 \\
\hline 11 & E M E M & - & 52 & $M L L L_{d}$ & 1982 \\
\hline 12 & $\mathrm{EM} \mathrm{E} \mathrm{H}_{\mathrm{d}}$ & - & 53 & M L L M & 1931 \\
\hline 13 & E M M L $L_{d}$ & 1961 & 54 & M L L H & - \\
\hline 14 & E M M M & 1915 & 55 & $\mathrm{~L} E \mathrm{E} \mathrm{L}_{\mathrm{d}}$ & - \\
\hline 15 & $\mathrm{EM} \mathrm{M} \mathrm{H}_{\mathrm{d}}$ & - & 56 & $L E E M_{d}$ & - \\
\hline 16 & E M L L $L_{d}$ & - & 57 & $\mathrm{~L} E \mathrm{E} \mathrm{H}_{\mathrm{d}}$ & - \\
\hline 17 & E M L M $\mathrm{d}_{\mathrm{d}}$ & 1949 & 58 & L E M L $\mathrm{L}_{\mathrm{d}}$ & - \\
\hline 18 & $\mathrm{E} \mathrm{M} \mathrm{L} \mathrm{H}_{\mathrm{d}}$ & - & 59 & $\mathrm{~L} E \mathrm{M} \mathrm{M}_{\mathrm{d}}$ & - \\
\hline 19 & E L E L $L_{d}$ & - & 60 & $\mathrm{~L} E \mathrm{M} \mathrm{H}_{\mathrm{d}}$ & - \\
\hline 20 & E L E M & - & 61 & $\mathrm{LE} \mathrm{L} \mathrm{L} \mathrm{d}_{\mathrm{d}}$ & - \\
\hline 21 & E L E H & - & 62 & L E L M & 1927 \\
\hline 22 & E L M L $\mathrm{L}_{\mathrm{d}}$ & 1925 & 63 & $\mathrm{LE} \mathrm{L} \mathrm{H}_{\mathrm{d}}$ & - \\
\hline 23 & $\mathrm{E} \mathrm{L} \mathrm{M} \mathrm{M}_{\mathrm{d}}$ & 1916,1939 & 64 & $\mathrm{~L} M E \mathrm{~L}_{\mathrm{d}}$ & 2001 \\
\hline 24 & $\mathrm{E} \mathrm{L} \mathrm{M} \mathrm{H}_{\mathrm{d}}$ & 1928 & 65 & $\mathrm{~L} M E \mathrm{M}_{\mathrm{d}}$ & 1971 \\
\hline 25 & $E L ~ L ~ L_{d}$ & 1944,2013 & 66 & $\mathrm{~L} M E \mathrm{H}_{\mathrm{d}}$ & - \\
\hline 26 & E L L M & - & 67 & $\mathrm{LM} \mathrm{M} \mathrm{L}_{\mathrm{d}}$ & - \\
\hline 27 & $\mathrm{E} \mathrm{L} \mathrm{L} \mathrm{H}_{\mathrm{d}}$ & $1956,1963,1973$ & 68 & $\mathrm{~L} \mathrm{M} \mathrm{M} \mathrm{M}$ & 2005 \\
\hline 28 & $M E E L_{d}$ & 1959,1989 & 69 & $\mathrm{~L} \mathrm{M} \mathrm{M} \mathrm{H}_{\mathrm{d}}$ & 2003 \\
\hline 29 & $\mathrm{MEE} \mathrm{M}_{\mathrm{d}}$ & - & 70 & $\mathrm{~L} \mathrm{M} \mathrm{L} \mathrm{L} \mathrm{L}_{\mathrm{d}}$ & 2012 \\
\hline 30 & $M E E H_{d}$ & 1970,1978 & 71 & L M L M & 1955 \\
\hline 31 & $M E M L_{d}$ & 2010 & 72 & $\mathrm{~L} \mathrm{M} \mathrm{L} \mathrm{H}_{\mathrm{d}}$ & 1933 \\
\hline 32 & $\mathrm{M} E \mathrm{M} \mathrm{M}_{\mathrm{d}}$ & 1943,1986 & 73 & L L E $\mathrm{L}_{\mathrm{d}}$ & 1983, 1991, 2009 \\
\hline 33 & $\mathrm{M} \mathrm{E} \mathrm{M} \mathrm{H}$ & $1922,1923,1934$ & 74 & L L E M & 1981 \\
\hline 34 & $M E ~ L ~ L_{d}$ & 1936 & 75 & $\mathrm{~L} \mathrm{LE} \mathrm{H}_{\mathrm{d}}$ & 1968 \\
\hline 35 & M E L M & - & 76 & L L M L $\mathrm{L}_{\mathrm{d}}$ & 1993, 2011 \\
\hline 36 & $M E L H_{d}$ & $1935,1951,1965$ & 77 & L L M M & 1919, 1984, 1987 \\
\hline 37 & $\mathrm{M} \mathrm{M} \mathrm{E} \mathrm{H}_{\mathrm{d}}$ & $\begin{array}{l}1921, \quad 1975, \quad 1992, \quad 1994, \\
2007\end{array}$ & 78 & $\mathrm{~L} \mathrm{~L} \mathrm{M} \mathrm{H}$ & 1985 \\
\hline 38 & $\mathrm{M} \mathrm{M} \mathrm{E} \mathrm{M}_{\mathrm{d}}$ & 1999 & 79 & L L L L $\mathrm{L}_{\mathrm{d}}$ & 1964 \\
\hline 39 & $\mathrm{M} \mathrm{M} \mathrm{E} \mathrm{H}_{\mathrm{d}}$ & 1937,1945 & 80 & L L L M & 2006 \\
\hline 40 & $\mathrm{M} M \mathrm{ML}_{\mathrm{d}}$ & 2015 & 81 & L L L H & $\begin{array}{llll}1917, & 1924, & 1929, & 1932, \\
1940, & 1942, & 1952, & 1969, \\
1980,1996 & \end{array}$ \\
\hline 41 & $\mathrm{MM} \mathrm{MM}_{\mathrm{d}}$ & - & & & \\
\hline
\end{tabular}

Note: $\mathrm{X}^{1}$ - the start date of the spring flood, $\mathrm{X}^{2}$ - the occurrence date of the peak discharge, $\mathrm{X}^{3}$ - the end date of the spring flood, $\mathrm{X}^{4}-$ the value of the peak discharge, $\mathrm{E}-$ early date, $\mathrm{M}$ - mean date, $\mathrm{L}$ - late date, $\mathrm{H}_{\mathrm{d}}$ - highest discharge, $\mathrm{M}_{\mathrm{d}}-$ mean discharge, $\mathrm{L}_{\mathrm{d}}$ - lowest discharge. 

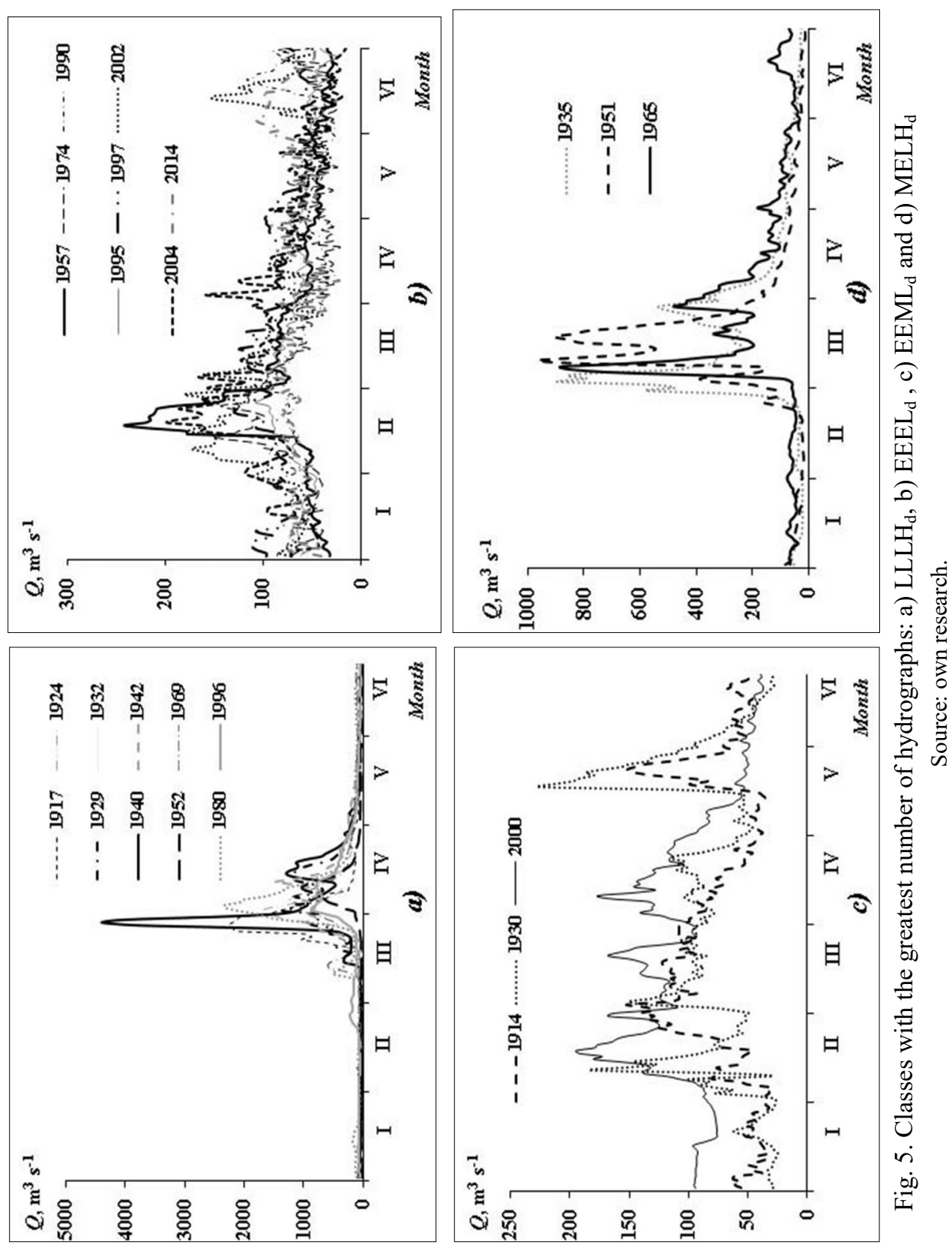
The greatest numbers of hydrographs (10 and 8 respectively) are in classes $\mathrm{LLLH}_{\mathrm{d}}$ and EEEL $($ Figs 5a, and 5b). These two classes represent the extreme values of selected characteristics. Class $\mathrm{MMEH}_{\mathrm{d}}$ contains four hydrographs and all other classes have a maximum of three hydrographs. Thirty-one classes have only one hydrograph, and twenty-five classes don't have hydrographs at all.

\section{DISCUSSION}

The proposed approach of the classification of hydrographs based on the faceted method can expand the knowledge inferred from the shape of the hydrograph. Traditional flood frequency analysis that is used in hydrology to estimate the design values for example, does not consider the hydrograph shape. However, the hydrograph shape has an important practical value, for example for the operation of the reservoirs, industrial and municipal water management, the smooth functioning of water transport, flood proofing, hydrological forecasting, etc. (Ternynck et al. 2015 and Khrystyuk et al. 2017). A proposed classification might open new avenues in this field.

The faceted method of classification could provide information about the hydrographs that have not been observed in the period of instrumental observations, but could occur in the future. Some classes in the study basin included hydrographs, which were observed at the start and end of the 20th century (Fig. $5 \mathrm{c}$ ). It can be expected, that hydrographs having similar shapes have the same conditions of runoff formation due to the cyclicity of climatic and hydrological processes. Analysis of climatic factors and their influence on the shape of the spring flood hydrograph can be conducted in future research.

Depending on the objectives of hydrological research, all classes of hydrographs can be grouped into groups according to certain features: mean discharges, peak discharges of spring floods, wet or dry phase of cyclic fluctuations, etc. This is facilitated by flexibility of faceted classification. If needed, additional attributes of classification can be used without the necessity of a complete update and complication of calculations.

\section{CONCLUSIONS}

The article presents the methodical approach of the spring flood hydrograph classification. The approach adopts the faceted system of classification using a multidimensional statistical approach with a controlled number of classes. Although the study focuses on classification of spring flood hydrographs, the presented methodology can be applied also to other hydrological phenomena like classification of the low flow periods, storm and rain floods or intra-annual streamflow distribution.

The faceted classification is used for data from the Southern Buh river and the period $1914-2015$. The results enable the extension of knowledge about the conditions of the spring floods formation in the studied river basin and can be important for hydrological calculations including long-term forecasting, water management, etc. 


\section{REFERENCES}

BAUZHA, T., GORBACHOVA, L. (2017). The features of the cyclical fluctuations, homogeneity, and stationarity of the average annual flow of the Southern Buh river basin. Annals of Valahia University of Targoviste. Geographical Series, 17, 5-17.

BRUNNER, M. I., VIVIROLI, D., FURRER, R., SEIBERT, J., FAVRE, A. C. (2018). Identification of flood reactivity regions via the functional clustering of hydrographs. Water Resources Research, 54(3), 1852-1867. DOI: https://doi.org/ 10.1002/2017WR021650.

CANDELA, A., BRIGANDİ, G., ARONICA, G. T. (2014). Estimation of synthetic flood design hydrographs using a distributed rainfall-runoff model coupled with a copulabased single storm rainfall generator. Natural Hazards Earth System Sciences, 14, 18191833. DOI: https://doi.org/10.5194/nhess-14-1819-2014.

CHOW, V. T., MAIDMENT, D. R., MAYS, L. M. (1988) Applied hydrology. New York (McGraw-Hill Book Company).

GJUNSBURGS, B., JAUDZEMS, G., GOVSHA, E. (2010). Hydrograph shape impact on the scour development with time at engineering structures in river flow. Scientific Journal of Riga Technical University, 11, 6-12.

GORBACHOVA, L., KHRYSTYUK, B. (2018). Calculation approaches of the probable maximum discharge of spring flood at ungauged sites in the Southern Buh River Basin, Ukraine. Annals of Valahia University of Targoviste. Geographical Series, 18, 107-120. DOI: 10.2478/avutgs-2018-0012.

HANNAH, D. M., SMITH, B. P. G., GURNELL, A. M., MCGREGOR, G. R. (2000). An approach to hydrograph classification. Hydrol. Processes, 14, 317-338.

HARTIGAN, J. A. (1975). Cluster Algorithms. New York (Wiley).

KHRYSTYUK, B., GORBACHOVA, L., KOSHKINA, O. (2017). The impact of climatic conditions of the spring flood formation on hydrograph shape of the Desna River. Meteorology Hydrology and Water Management, 5, 63-70. DOI: https://doi.org/10.26491/ mhwm/67914.

MAKAROVA, N. V., VOLKOVA, V. B. (2015). Computer science. St. Petersburg (Peter).

OPPEL, H., MEWES, B., SCHUMANN, A. (2018). Classification of flood hydrographs with unsupervised learning in the spectral space. EGU General Assembly 2018, Geophysical Research Abstracts, 20, EGU2018-2220.

OPPEL, H., SCHUMANN, A. (2018). Machine learning-based typing of flood hydrographs to characterize extreme events. EGU General Assembly 2018, Geophysical Research Abstracts, 20, EGU2018-2218.

PERKINS, R. M., JONES, J. A. (2008). Climate variability, snow, and physiographic controls on storm hydrographs in small forested basins, western Cascades, Oregon. Hydrological Processes, 22, 4949-4964. DOI: 10.1002Ihyp.7117.

PHILLIPS, C., HILL, K., PAOLA, C. (2016). Quantifying the effects of hydrograph shape and flow transience on coarse sediment bed load transport. EGU General A ssembly 2016. Geophysical Research Abstracts, 18, EGU2016-15171.

POL, J. C. (2014). Hydrograph shape variability on the river Meuse. Master Thesis. Delft (Delft University of Technology).

RANGANATHAN, S. R. (2006). Colon classification. Delhi (Ess Publications).

RUSHMER, E. L., RUSSEL, A. J., TWEED, F. S., KNUDSEN, O., MARREN, P. M. (2002). The role of hydrograph shape in controlling glacier outburst flood (jôkulhlaup) sedimentation. In Dyer, F. J., Thoms, M. C., Olley, J. C., eds. Proceedings of an international symposium held at Alice Springs, Australia. September 2002. IAHS Publ., 276, pp. 305-313.

SHAKIRZANOVA, Zh. R., KAZAKOVA, A. O. (2015). Hydrometeorological factors and characteristics spring flood in basin of the Southern Bug in current climatic conditions. Visnik Odes'kogo deržavnogo ekologičnogo universitetu, 19, 100-106. 
TERNYNCK, C., ALAYA, M. A. B., CHEBANA, F., DABO-NIANG, S., OUARDA, T. B. M. J. (2015). Streamflow hydrograph classification using functional data analysis. Journal of Hydrometeorology, 17, 327-344. DOI: 10.1175/JHM-D-14-0200.1.

YUE, S., OUARDA, T., BOBEE, B., LEGENDRE, P., BRUNEAU, P. (2002). Approach for describing statistical properties of flood hydrograph. Journal of Hydrologic Engineering, 7, 147-153. DOI:10.1061/(ASCE)1084-0699(2002)7:2(147).

\author{
Borys Khrystiuk, Liudmyla Gorbachova, Viktoria Prykhodkina
}

\title{
FAZETOVÁ KLASIFIKÁCIA HYDROGRAMOV POČAS JARNÝCH POVODNÍ NA RIEKE JUŽNÝ BUG
}

Analýza tvarov hydrogramov je dôležitým nástrojom výskumu, ked’že ich priebeh odráža vplyv hydrologických, hydrobiologických, hydromorfologických a hydrochemických procesov pôsobiacich v povodiach riek. Súčast'ou takejto analýzy je aj klasifikácia hydrogramov. Zoskupenie hydrogramov podobného tvaru do klasifikačných tried môže prispiet' $\mathrm{k}$ lepšiemu pochopeniu rôznych hydrologických procesov, najmä v období povodní a sucha.

Klasifikovat' akékol'vek objekty je vo všeobecnosti možné dvomi základnými spôsobmi: hierarchicky alebo fazetovo. Hierarchická klasifikácia vedie k vytvoreniu hierarchickej stromovej štruktúry. Fazetová metóda klasifikácie, ktorú navrhol indický vedec Sh. R. Ranganathan v roku 1933, je založená na použití súboru sémanticky prepojených aspektov, ktoré sú kombinované podl'a potreby tak, aby sa vytvoril komplexný pojem. Pre fazetovú klasifikáciu je charakteristická jej flexibilná štruktúra, čo umožňuje jej široké využitie pri triedení komplexných objektov.

V tomto príspevku predstavujeme metodiku klasifikácie hydrogramov na príklade hydrologických údajov o jarných povodniach v povodí rieky Južný Bug na Ukrajine. Navrhovaný metodický prístup vychádza z fazetového klasifikačného systému, využívajúc viacrozmerný štatistický prístup a kontrolovaný počet tried. Metóda bola testovaná na údajoch o denných prietokoch v študovanom povodí v období rokov $1914-2015$. Hydrogramy znázorn̆ujúce priebeh jarných povodní charakterizuje značná miera rozmanitosti a komplexnosti.

Celkovo bolo analyzovaných 102 hydrogramov jarných povodní, ktoré boli rozdelené do tried na základe údajov o maximálnom prietoku, začiatku, kulminácii a konci jarnej povodne. Dve z 81 všetkých možných tried obsahujú viac ako osem hydrogramov, viaceré naopak zostali prázdne. Predpokladá sa, že hydrogramy s podobným priebehom poukazujú na rovnaké podmienky tvorby odtoku v čase, ktorý zaznamenávajú, a tým aj na cyklickost' klimatických a hydrologických procesov. Klasifikácia tak poskytuje zaujímavé porovnanie charakteru jarných periód v rokoch, ktoré môžu byt' od seba vzdialené mnoho desat'ročí. Dalším krokom vo výskume potom môže byt' analýza klimatických faktorov vplývajúcich na tvorbu jarných povodní a ich vplyv na tvary hydrogramov v rôznych triedach.

Aj ked'sa táto štúdia zameriava na klasifikáciu hydrogramov jarných povodní, prezentovaná metodika môže byt' dobre uplatnitel'ná aj pri analýze iných hydrologických ukazovatel'ov, napríklad pri klasifikácii období nízkych prietokov, pri výskume búrok a dažd'ových povodní, alebo pri skúmaní rozdelenia odtoku v rámci roka. 